First publ. in: Planta 185 (1991), pp. 246-254

\title{
Early defence responses of cowpea (Vigna sinensis L.) induced by non-pathogenic rust fungi
}

\author{
W. Fink, M. Haug, H. Deising, and K. Mendgen* \\ Universität Konstanz, Fakultät für Biologie, Phytopathologie, Universitätsstrasse 10, W-7750 Konstanz, Federal Republic of Germany
}

Received 9 February; accepted 4 May 1991

\begin{abstract}
In cowpea (Vigna sinensis L.) leaves the pathogenic rust fungus Uromyces vignae and the non-pathogens $U$. appendiculatus and $U$. viciae-fabae developed similarly to give rise to more than $80 \%$ haustorial mother cells. Whereas $U$. vignae was able to sporulate, the nonpathogens were stopped either after formation of some haustoria ( $U$. appendiculatus) or immediately after formation of haustorial mother cells ( $U$. viciae-fabae). Approximately $30 \%$ of the cells in contact with haustorial mother cells of the two non-pathogens showed autofluorescence and deposition of phloroglucinol/HClpositive material. The early defence reactions of $V$. sinensis include induction of phenylalanine ammonia-lyase (PAL, EC 4.3.1.5) and extracellular peroxidase (POD, EC 1.11.1.7) activity as early as $10 \mathrm{~h}$ and $24 \mathrm{~h}$ after inoculation, respectively. Probing Western blots with heterologous monospecific anti-PAL serum showed that pathogenesis-induced increases in enzyme activity are the result of de novo synthesis. Native polyacrylamide gel electrophoresis revealed the specific induction of two extracellular acidic POD forms in cowpea inoculated with the non-pathogens. Both PAL and apoplasmic POD activities were highest in $U$. viciae-fabae-, intermediate in $U$. appendiculatus - and low in $U$. vignae-inoculated or talcum-treated control plants. The timing of increasing PAL and extracellular POD activities in relation to deposition of lignin or lignin-like material in mesophyll cell walls indicates the involvement of lignification in the early defence of $V$. sinensis against biotrophic fungal parasites. Analysis of the substrate specificity of the inducible POD forms, separated and partially purified by chromatofocusing, showed that apoplasmic PODs preferentially oxidize the naturally occurring substrate coniferyl alcohol. These results support the assumption that POD-mediated lignification is involved in the expression of non-host resistance of cowpea to rust fungi.
\end{abstract}

* To whom correspondence should be addressed

Abbreviations: $\mathrm{IWF}=$ intercellular washing fluid $\mathrm{PAL}=$ phenylalanine ammonia-lyase; p.i. = post inoculation; $P O D=$ peroxidase; SDS-PAGE = sodium dodecyl sulfate-polyacrylamide gel electrophoresis
Key words: Defense response to non-pathogens - Lignification - Non-host resistance - Peroxidase (extracellular) - Phenylalanine ammonia-lyase - Rust fungi - Vigna

\section{Introduction}

In a natural environment, plants are exposed to a variety of potentially pathogenic microorganisms. While a pathogen is able to cause disease on one or a few plant species, it is usually a non-pathogen on most others. This type of resistance has been termed non-host resistance. In contrast to host resistance which depends on a single or a few resistance genes, the complex genetics of non-host resistance seems more difficult to overcome (Heath 1987; Luke et al. 1987).

The development of the pathogenic cowpea rust fungus Uromyces vignae and the non-pathogen $U$. appen diculatus on cowpea (Vigna sinensis), and post-infectional cytological alterations have already been described in detail (Heath 1972; Elmhirst and Heath 1987, 1989). While the early development of infection structures of both rust fungi proceeds similarly on cowpea plants the non-pathogen develops only as far as haustorial mothercell formation and only occasionally primary haustoria are formed. In the non-host interaction, fungal-infection structures autofluorescence and-or turn brownish and the mesophyll cells containing haustoria show yellow autofluorescence (Elmhirst and Heath 1989). In heatshocked leaves, however, these phenomena are significantly reduced and the non-pathogenic rust fungus is also able to establish primary haustoria. Since yellow autofluorescence of plant cell walls is taken as evidence for lignification (Reisener et al. 1986; Tiburzy and Reisener 1990) these microscopical results indicate active defence reactions in interactions between higher plants and rust fungi. As shown with virus- or Phytophthorainfected cowpea plants, however, defence reactions in this species can include the release of substances toxic to fungi, induction of peroxidase isoenzymes, formation of pathogenesis-related proteins and synthesis of isoflavo- 
noid phytoalexins (Bailey 1973; Coutts 1978; Ehara and Yamanaka 1981; Wagih and Coutts 1981, 1982a, b; Ando et al. 1984; Ralton et al. 1988).

A key enzyme in the phenylpropanoid pathway giving rise to synthesis of aromatic compounds used in both phytoalexin synthesis and lignification is phenylalanine ammonia-lyase (PAL). Abiotic stress factors like $\mathrm{CuCl}_{2}$ or UV light (Munn and Drysdale 1975) as well as biotic substances like an elicitor from cell walls of Phytophthora megasperma var. sojae (Hattori and Ohta 1985) can induce PAL activity in Vigna cell-suspension cultures. In these cases, the induction of PAL was accompanied by phytoalexin synthesis, and Ralton et al. (1988) report a correlation between induced PAL activity and resistance of different $V$. sinensis varieties to Phytophthora vignae.

Early electron-microscopical studies have shown the presence of peroxidase (POD) activity in mesophyll cellwall layers in contact with rust fungi (Mendgen 1975). The induction of POD forms considered to be involved in lignification of plant cell walls has been reported for numerous plant-pathogen systems (e.g. Heath 1980; Gaspar et al. 1982) but the physiological importance of these enzymes has been addressed in only a few cases (Catedral and Daly 1976; Espelie and Kolattukudy 1985 ). Only occasionally have certain pathogens been found to induce specific POD forms (e.g. Catedral and Daly 1976; Kerby and Somerville 1989).

While substantial data concerning non-host resistance of mono- and dicotyledonous plants to rust fungi are available on the microscopical level (Elmhirst and Heath 1989 , and literature therein), little is known about the mechanism of non-host resistance on the biochemical level (Fink et al. 1990). In this paper, biochemical responses of a dicotyledonous plant ( $V$. sinensis) to different nonpathogens are described for the first time. The rapid induction of PAL and acidic POD forms, as well as the substrate specificity of these extracellular peroxidases, are discussed in relation to lignification as a possible mechanism of non-host resistance.

\section{Materials and methods}

Plant and fungal material. Vigna sinensis cv. California blackeye (cowpea; W. Atlee Burpee Company, Warminster, Pa., USA) plants were grown in vermiculite $\left(40 \mathrm{~cm}^{2}\right.$ per plant) in a growth chamber. The photoperiod was $16 \mathrm{~h}\left(140 \mathrm{~W} \cdot \mathrm{m}^{-2}\right)$ at $21^{\circ} \mathrm{C}$ and $50 \%$ relative humidity. During the 8 -h dark period the conditions were set to $19^{\circ} \mathrm{C}$ and $85 \%$ relative humidity. Twelve-day-old primary leaves were either inoculated with the pathogenic cowpea rust fungus Uromyces vignae (isolate CPR1) or with the nonpathogens $U$. appendiculatus (isolate SWBR2) or U. viciae-fabae (isolate I2). In all experiments, freshly harvested uredospores were used.

To inoculate plants, $5 \mathrm{mg}$ spores were mixed with the same amount of talcum powder and suspended in $1 \mathrm{ml}$ tap water. At the beginning of the dark period $1 \mathrm{ml}$ of inoculum was applied to the abaxial surface of 10 primary leaves using a brush. The inoculated plants were subsequently kept at $100 \%$ relative humidity for $24 \mathrm{~h}$. Control plants were treated with a talcum suspension without uredospores.

Light microscopy. Leaf samples of approx. $50 \mathrm{~mm}^{2}$ were cleared and stained as described by Rohringer et al. (1976) with the exception that Uvitex 2B (Diethanol; Ciba Geigy, Basel, Switzerland) was used instead of Calcofluor. Fungal infection structures were observed using a Zeiss fluorescence microscope (G 436, FT 510, LP 520 for blue fluorescence and G 365, FT 395, LP 420 for yellow autofluorescence; Zeiss, Oberkochen, FRG). To stain lignin, the Uvitex 2B-stained leaf samples were incubated in a $0.1 \%(\mathrm{w} / \mathrm{v})$ ethanolic phloroglucinol solution for $30 \mathrm{~s}$ and a drop of concentrated $\mathrm{HCl}$ was added after brief heating.

Preparation of leaf homogenates and intercellular washing fluid $(I W F)$. To extract PAL activity, freshly harvested leaves were frozen in liquid nitrogen and homogenized with mortar and pestle. An aliquot of $3 \mathrm{ml}$ of $50 \mathrm{mM}$ borate buffer, $\mathrm{pH} 8.8$ (Hattori and Ohta 1985) was added per $g$ leaf powder. The suspension was stirred for $30 \mathrm{~min}$ at $4^{\circ} \mathrm{C}$ and subsequently filtered through two layers of cheesecloth. After centrifugation $\left(20000 \cdot \mathrm{g}, 20 \mathrm{~min}, 4^{\circ} \mathrm{C}\right)$ the supernatant was stored in aliquots at $-20^{\circ} \mathrm{C}$. To measure enzyme activity the crude extract was used immediately after thawing and not frozen again.

Extracellular PODs were isolated by the infiltration method described by Rohringer et al. (1983), with the following modifications: After removing the central vascular bundles, halves were infiltrated with $0.1 \mathrm{M} \mathrm{Na-phosphate} \mathrm{buffer,} \mathrm{pH} 7.0$, for $20 \mathrm{~min}$. The IWF was recovered by centrifugation $\left(410 \cdot \mathrm{g}, 20 \mathrm{~min}, 4^{\circ} \mathrm{C}\right)$. To determine plant cell integrety, malate dehydrogenase was used as a cytoplasmic marker enzyme. To compare extracellular and intracellular malate-dehydrogenase activities, leaves were extracted in $0.1 \mathrm{M}$ Na-phosphate buffer, $\mathrm{pH} 7.0$, as described above.

Enzyme assays. Activity of PAL was measured as described by Green et al. (1975). The assay contained crude extract and $3 \mathrm{mM}$ L-phenylalanine in $50 \mathrm{mM}$ borate buffer, $\mathrm{pH} 8.8$. Reaction time was $2 \mathrm{~h}$ at $30^{\circ} \mathrm{C}$. Activity of POD in IWF and column fractions was measured according to Rathmell and Sequeira (1974) using guajacol (extinction coefficient $\varepsilon_{470 \mathrm{~nm}}=6.39 \mathrm{~mol}^{-1} \cdot \mathrm{cm}^{-1}$ ) as the substrate. The assay mixture contained the enzyme sample, $0.33 \mathrm{mM}$ guajacol and $0.13 \mathrm{mM} \mathrm{H}_{2} \mathrm{O}_{2}$ in $25 \mathrm{mM} \mathrm{Na}$-acetate buffer, $\mathrm{pH} 5.5$. To analyze the substrate specificity of extracellular POD forms, 3-amino-9-ethylcarbazol (Graham et al. 1964) and coniferyl alcohol $\left(\varepsilon_{260 \mathrm{~nm}}=2.2 \mathrm{~mol}^{-1} \cdot \mathrm{cm}^{-1}\right.$; Pedreño et al. 1989) were used as alternative substrates at 0.04 and $0.2 \mathrm{mM}$ final concentration.

Immunotitration, electroblotting and immunodetection of $P A L$. To immunotitrate PAL, $600 \mu \mathrm{l}$ of crude extract, varying amounts $(0-100 \mu \mathrm{l})$ of crude rabbit anti-PAL serum and $50 \mathrm{mM}$ borate buffer, $\mathrm{pH} 8.8$, to give a final volume of $700 \mu 1$ were mixed and incubated on ice for $4 \mathrm{~h}$. After pelleting the immune complexes $\left(15000 \cdot g, 15 \mathrm{~min}, 4^{\circ} \mathrm{C}\right)$, PAL activity was measured in the supernatant.

For Western blotting, crude leaf extracts were subjected to sodium dodecyl sulfate-polyacrylamide gel electrophoresis (SDS-PAGE; Laemmli 1970); the stacking gel was 4\%, the separation gel $(95 \times 140$ [width] $\times 1.5 \mathrm{~mm})$ was $10 \%$ polyacrylamide. For stacking of proteins, $15 \mathrm{~mA}$, and for separation, $30 \mathrm{~mA}$, were applied. Myosin $(205 \mathrm{kDa}), \beta$-galactosidase $(116 \mathrm{kDa})$, phosphorylase $\mathrm{b}(97 \mathrm{kDa})$, bovine serum albumin (BSA; $67 \mathrm{kDa})$, carbonic anhydrase $(29 \mathrm{kDa})$, chymotrypsinogen $(25 \mathrm{kDa})$, and myoglobin $(17.8 \mathrm{kDa})$; all from Serva, Heidelberg, FRG were used as molecular-weight markers. The separated proteins were electroblotted onto a polyvinylidene difluoride (PVDF, Immobilon) membrane (Millipore, Bedford, Mass., USA) for $4 \mathrm{~h}$ using the buffer system described by Kyhse-Andersen (1984) and a current of $1 \mathrm{~mA} \cdot \mathrm{cm}^{-2}$. The PVDF membrane was subsequently incubated with $15 \%$ skimmed milk powder (approx. $5 \%$ protein) in TBS $(50 \mathrm{mM}$ Tris, $200 \mathrm{mM} \mathrm{NaCl}, \mathrm{pH} 7.2$ ). For immunodetection of PAL, primary antibody raised against the parsley enzyme was diluted 500 -fold with TBS containing $2.5 \%$ skimmed milk powder and incubated with the PVDF membrane for $4 \mathrm{~h}$ at $4^{\circ} \mathrm{C}$. After washing with TBS for $30 \mathrm{~min}$ (three buffer changes), the membrane was incubated with the secondary antibody (biotinylated goat anti-rabbit; Sigma, Deisenhofen, FRG), diluted 4000 -fold with TBS containing $2.5 \%$ skimmed milk powder. After washing as described above, the 
bound biotinylated secondary antibody was allowed to react with streptavidin-conjugated alkaline phosphatase (Boehringer Mannheim, Mannheim, FRG), diluted 1000-fold in TBS containing 2.5\% skimmed milk powder. After washing the membrane for $60 \mathrm{~min}$ (five buffer changes) alkaline-phosphatase activity was detected as described by Deising and Rudolph (1987)

Native $P A G E$ and detection of peroxidase activity in gels. The IWF of rust-inoculated and control plants was adjusted to contain $10 \%$ glycerol and applied directly to either basic or acidic polyacrylamide gels. The stacking gels were $4 \%$ polyacrylamide, the separation gels $(95 \times 140 \times 1.5 \mathrm{~mm})$ were either $10 \%$ (basic gels) or contained a linear polyacrylamide gradient from 10 to $15 \%$ (acidic gels). For separation of basic and acidic peroxidase forms, the buffer systems $\mathrm{N}^{\circ} .7$ (stacking gel $\mathrm{pH} 6.7$, separation gel $\mathrm{pH} 5.2$ ) and $\mathrm{N}^{\circ}$.1a (stacking gel pH 6.9, separation gel pH 8.9) described by Maurer (1971) were used. The gels were run at $10 \mathrm{~mA}$ at $4^{\circ} \mathrm{C}$ until the front marker (bromophenol blue in basic gels, methyl green in acidic gels) reached the bottom of the gel. After separation the basic gels were equilibrated with $0.1 \mathrm{M} \mathrm{Na}$-acetate buffer, $\mathrm{pH} 5.0$ for $30 \mathrm{~min}$ at room temperature. Peroxidases were stained using 3-amino-9-ethylcarbazol as the substrate (Graham et al. 1964).

Column chromatography. Chromatofocusing in the acidic range was performed using $\left(\mathrm{DEAE}=\mathrm{Si} 500(0.02-0.04 \mathrm{~mm} ;\right.$ Serva $)$ at $4^{\circ} \mathrm{C}$. The column was equilibrated with $25 \mathrm{mM} \beta$-alanine/ $\mathrm{HCl}, \mathrm{pH} 4.5$ ). Ampholytes (Servalyt 2-4; Serva) were used to generate the $\mathrm{pH}$ gradient.

For molecular-weight determination, IWF or fractions of chromatofocused proteins were applied to a Sephadex G75-SF (Pharmacia, Freiburg, FRG) column ( $800 \mathrm{~mm}$ long, $17 \mathrm{~mm}$ i.d.), equilibrated with $0.1 \mathrm{M}$ Na-phosphate buffer, $\mathrm{pH} 7.0$. The flow rate was $5.1 \mathrm{ml} \cdot \mathrm{cm}^{-2} \cdot \mathrm{h}^{-1}$. Bovine serum albumin $(67 \mathrm{kDa})$, ovalbumin $(45 \mathrm{kDa})$, soybean trypsin inhibitor $(24 \mathrm{kDa})$, myoglobin $(17.8 \mathrm{kDa})$, and cytochrome $c(12.5 \mathrm{kDa}$; all from Serva) were used as molecular-weight markers.

Chromatography was carried out at $4^{\circ} \mathrm{C}$.

\section{Results}

Light-microscopical observations during pathogenesis. During differentiation of infection structures, the pathogenic cowpea rust fungus Uromyces vignae and the two non-pathogens $U$. appendiculatus and $U$. viciae-fabae exhibited no appreciable differences within the first $24 \mathrm{~h}$ after inoculation. The fungi had penetrated through the stomata and formed substomatal vesicles and infection hyphae. More than $80 \%$ of the sporelings had differentiated haustorial mother cells after $24 \mathrm{~h}$. In the compatible interaction the rust fungus proceeded to differentiate primary haustoria and $48 \mathrm{~h}$ p.i. large colonies of rust mycelium with secondary haustoria were observed; $7 \mathrm{~d}$ after inoculation $U$. vignae began to sporulate. The nonpathogen $U$. viciae-fabae stopped growth after differentiation of haustorial mother cells. Uromyces appendiculatus developed similarly except that $8 \%$ of its haustorial mother cells produced primary and some secondary haustoria $48 \mathrm{~h}$ p.i. The structures formed by both nonpathogens had disintegrated by $7 \mathrm{~d}$ p.i.

Talcum-treated control plants and those infected with the pathogen $U$. vignae exhibited neither autofluorescence nor necrosis during the first $48 \mathrm{~h}$ p.i. Plants infected with the non-pathogens showed no reaction of the mesophyll cells until $16 \mathrm{~h}$ p.i. At $24 \mathrm{~h}$ p.i., however, approx. $30 \%$ of those mesophyll cells in contact with
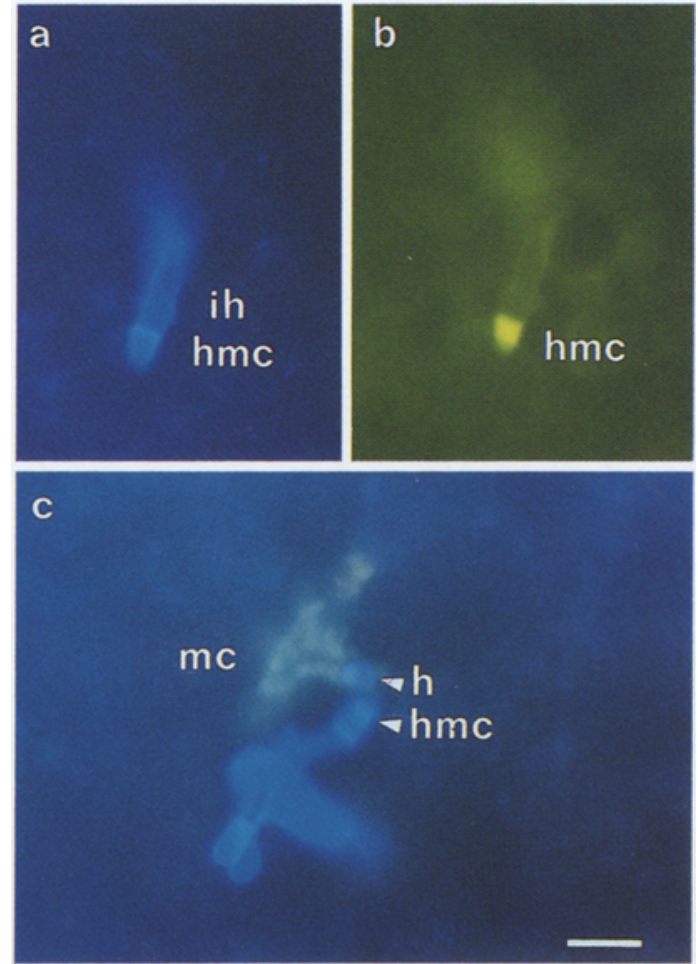

Fig. 1a-c. Rust infection structures in cowpea leaves $24 \mathrm{~h}$ after inoculation. a Blue fluorescence of Uromyces viciae-fabae infection hypha $(i h)$ and haustorial mother cell $(h m c)$ after staining with diethanol. b Yellow autofluorescence of the haustorial mother cell of U. viciae-fabae. $\mathbf{c}$ Yellow autofluorescence of a cowpea mesophyll cell $(m c)$ containing a haustorium $(h)$ of $U$. appendiculatus. The fungal structures were stained as in a and fluoresce blue. The double exposure was made using yellow and blue light barrier filters, respectively. Bars $=20 \mu \mathrm{m} ; \times 384$

haustorial mother cells fluoresced (Fig. 1c), and onethird of the fluorescing cells had collapsed. In contrast, mesophyll cells in contact with substomatal vesicles or infection hyphae did not exhibit autofluorescence. The number of autofluorescing areas in contact with haustorial mother cells did not seem to be altered at later stages of pathogenesis ( $48 \mathrm{~h}$ p.i.), but each had expanded to 5-30 mesophyll cells. Haustoria of $U$. appendiculatus were found in fluorescing as well as in non-fluorescing cells. Whereas no signs of fungal senescence were observed in both non-host interactions after $24 \mathrm{~h}$, infection hyphae and haustorial mother cells autofluoresced andor were of brownish colour at $48 \mathrm{~h}$ p.i. (Fig. 1a, b).

Since yellowish autofluorescence maybe taken as an indication for lignin and lignin-like compounds, the tissue was stained with phloroglucinol- $\mathrm{HCl}$. While all cell walls of the autofluorescing plant cell were stained, nonfluorescing mesophyll cells did not show evidence of lignification.

Phenylalanine ammonia-lyase. Activity of PAL in Vigna sinensis leaf homogenates had a $\mathrm{pH}$ optimum between 8.5 and 9.0. In talcum-treated control plants and in plants infected with the pathogenic rust fungus $U$. vignae, the activity increased only slightly during the $48 \mathrm{~h}$ after 


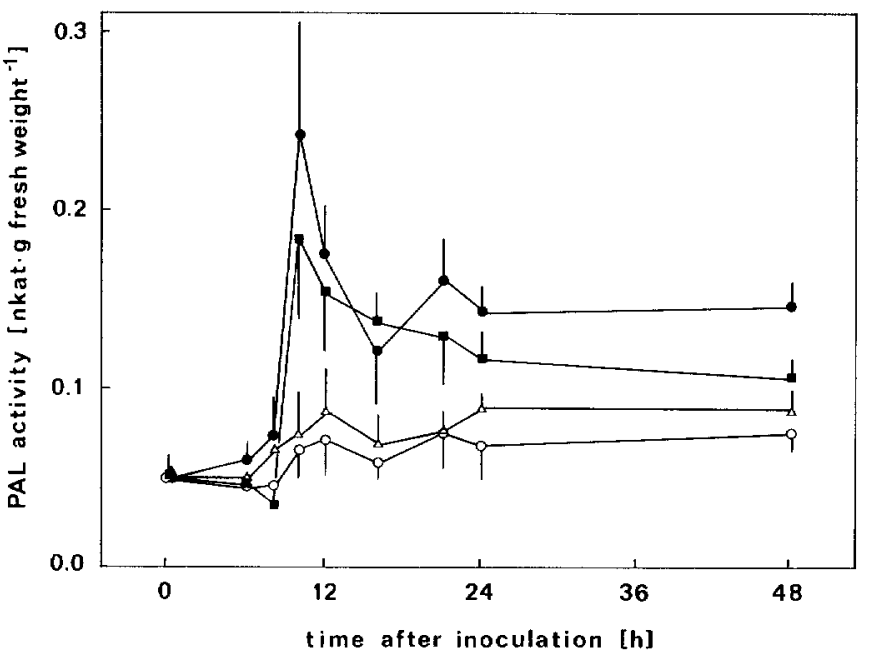

Fig. 2. Time course of PAL activity in leaf homogenates of Vigna sinensis, showing talcum-treated control $(O-O)$, leaves inoculated with the pathogenic rust fungus Uromyces vignae $(\Delta-\triangle)$, and leaves inoculated with the non-pathogens $U$. appendiculatus ( $-\mathbf{m}$ ) and U. viciae-fabae $(\bullet-\bullet)$. The data are means of three separate experiments. Vertical bars represent maximal errors

treatment (Fig. 2). In both non-host interactions, PAL activity had increased significantly at $10 \mathrm{~h}$ p.i. Maximal enzyme activities were $350 \%$ of control plants in $U$. viciae-fabae-inoculated, and $250 \%$ in $U$. appendiculatusinoculated plants.

To address the question whether the increase in PAL activity in $U$. viciae-fabae-inoculated plants is due to de novo synthesis of PAL protein or to post-translational activation of the pre-existing inactive enzyme, Western blots were probed with anti-PAL serum raised in rabbit. As shown in Fig. 3a the anti-PAL immunoglobulins specifically recognized a single band of $80 \mathrm{kDa}$. The intensity of the bands correlated with the enzyme-activity data (Fig. 2). Immuno-titration of PAL activity (Fig. 3b) showed that the antiserum raised against PAL from parsley recognized the cowpea enzyme. The addition of $167 \mu \mathrm{l}$ anti-PAL serum to $1 \mathrm{ml}$ crude leaf homogenate decreased the enzyme activity by $81 \%$.

Apoplasmic POD activity. Since PODs involved in cellwall lignification are localized in the apoplast we used the leaf-infiltration method (Rohringer et al. 1983) to specifically isolate extracellular forms of this enzyme. Malate-dehydrogenase activity was used as a measure for leaf cell integrity. Based on fresh weight of the leaves the percentage of malate-dehydrogenase activity in the IWF was $0.05 \%$ of the total activity found in leaf homogenates.

In talcum control plants POD activity increased twofold during $96 \mathrm{~h}$ p.i. A similar kinetic was found in the compatible interaction, but in both non-host interactions POD activities increased considerably after $24 \mathrm{~h}$ p.i. Maximal values measured at $48 \mathrm{~h}$ p.i. were $420 \%$ of control plants in $U$. viciae-fabae-inoculated plants and $270 \%$ in plants inoculated with $U$. appendiculatus. After $48 \mathrm{~h}$ the POD activity remained constant (Fig. 4).
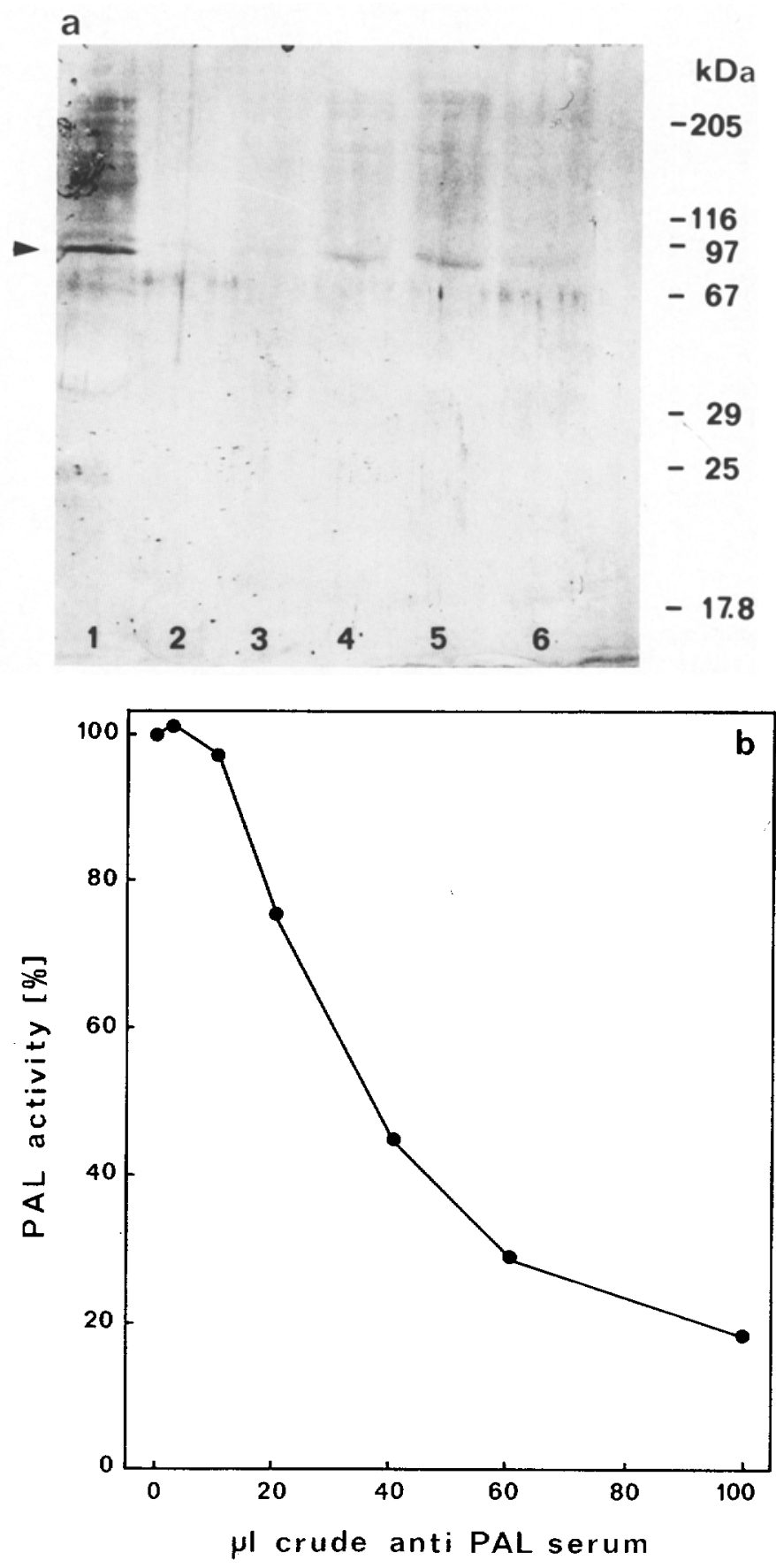

Fig. 3. a Immunodetection of PAL protein after SDS-PAGE and electroblotting. The following crude leaf homogenates $(20 \mu 1$ each) were applied to the gel: Lane 1, parsley control containing $6.8 \mathrm{nkat}$ PAL activity; lanes 2-6, Vigna sinensis inoculated with Uromyces viciae-fabae. Lane $2,0 \mathrm{~h}$ p.i. (2.4 nkat); lane $3,8 \mathrm{~h}$ p.i. (3.2 nkat); lane $4,10 \mathrm{~h}$ p.i. (13.4 nkat); lane $5,12 \mathrm{~h}$ p.i. (10.5 nkat) and lane 6 , $24 \mathrm{~h}$ p.i. (7.0 nkat PAL activity). The position of PAL protein is indicated by an arrowhead. $\mathbf{b}$ Immunotitration of PAL activity. Leaf homogenates of $V$. sinensis were prepared $10 \mathrm{~h}$ after inoculation with $U$. viciae-fabae and titrated with rabbit serum raised against PAL from parsley

Multiple $P O D$ forms. To detect multiple POD forms by native PAGE, two different buffer systems were used to separate acidic and basic POD forms. Figure 5 shows the acidic extracellular PODs in a $10 \%$ polyacrylamide gel. 


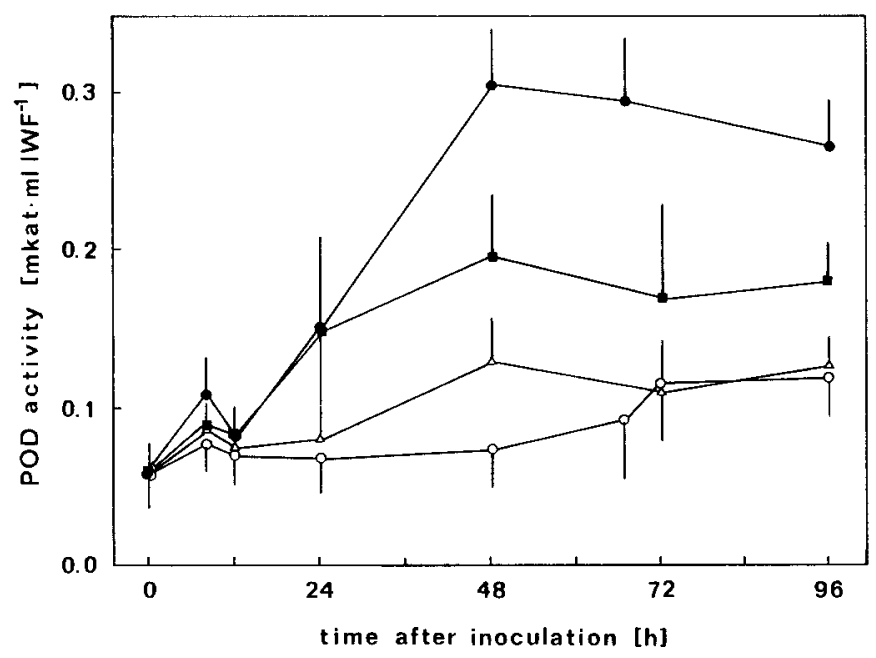

Fig. 4. Time course of POD activity in the IWF of Vigna sinensis, showing talcum-treated control $(O-O)$, leaves inoculated with the pathogenic rust fungus Uromyces vignae $(\Delta-\Delta)$, and leaves inoculated with the non-pathogens $U$. appendiculatus $(\square-\square)$ and U. viciae-fabae $(\bullet-)$. The data are means of three separate experiments. Vertical bars represent maximal errors
In basic gels, control plants showed a faint acidic POD band. After inoculation with the pathogenic rust fungus $U$. vignae, the zymogram was comparable to that observed with control plants. Beginning from $16 \mathrm{~h}$ p.i. with the non-pathogens $U$. viciae-fabae and $U$. appendiculatus, pronounced increases in acidic extracellular POD forms were visible. The bands could usually be resolved as a double band designated POD1 and POD2. In acidic gels the IWF of control plants and that of plants inoculated with the three rust fungi showed four identical basic POD bands. The pattern was stable during the entire time course of the experiment.

Chromatofocusing of non-pathogen-induced POD forms. To further characterize and separate the pathogenesisinducible acidic POD forms, IWF was isolated from talcum controls and from $U$. viciae-fabae-inoculated plants $48 \mathrm{~h}$ p.i., and subjected to chromatofocusing. Basic POD forms (peak A) detected in controls and $U$. viciae-fabae-inoculated plants did not bind to the column. Two peaks $(B, C)$ eluted from the DEAE $=S i 500$ column at pH 3.5 and $\mathrm{pH} 3.0$ (Fig. 6b). These latter peaks a
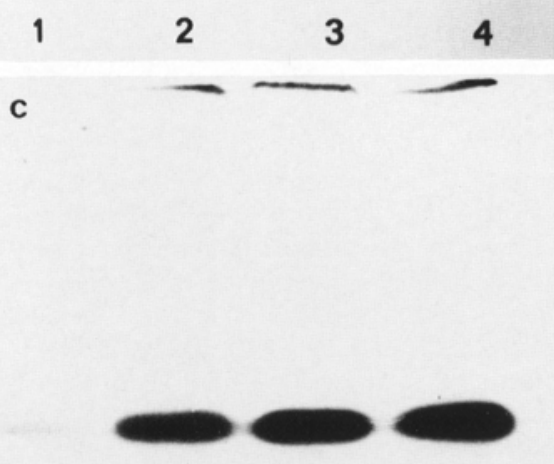

1

2 b.

d
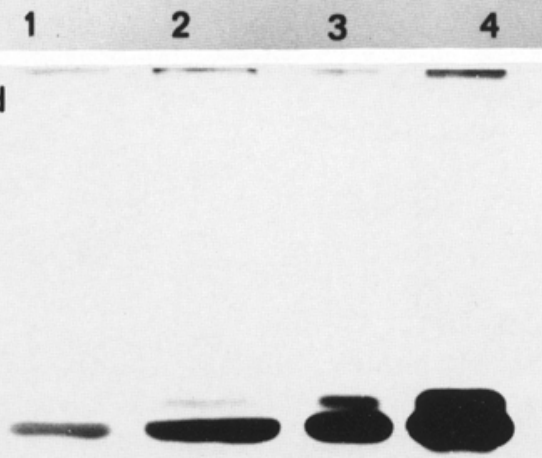

1
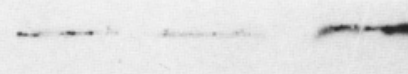

POD 1 POD 2
Fig. 5a-d. Patterns of acidic peroxidases after separation of IWF of $V$. sinensis by native PAGE. Samples were taken $16 \mathrm{~h}$ (lane 1), $24 \mathrm{~h}$ (lane 2), $48 \mathrm{~h}$ (lane 3) and $72 \mathrm{~h}$ (lane 4) after talcum treatment (a), after inoculation with Uromyces vignae (b), $U$. appendiculatus (c) or $U$. viciae-fabae (d). Of each sample $75 \mu \mathrm{l}$ were loaded. Peroxidase activity was visualized using 3-amino-9-ethylcarbazole as the substrate 


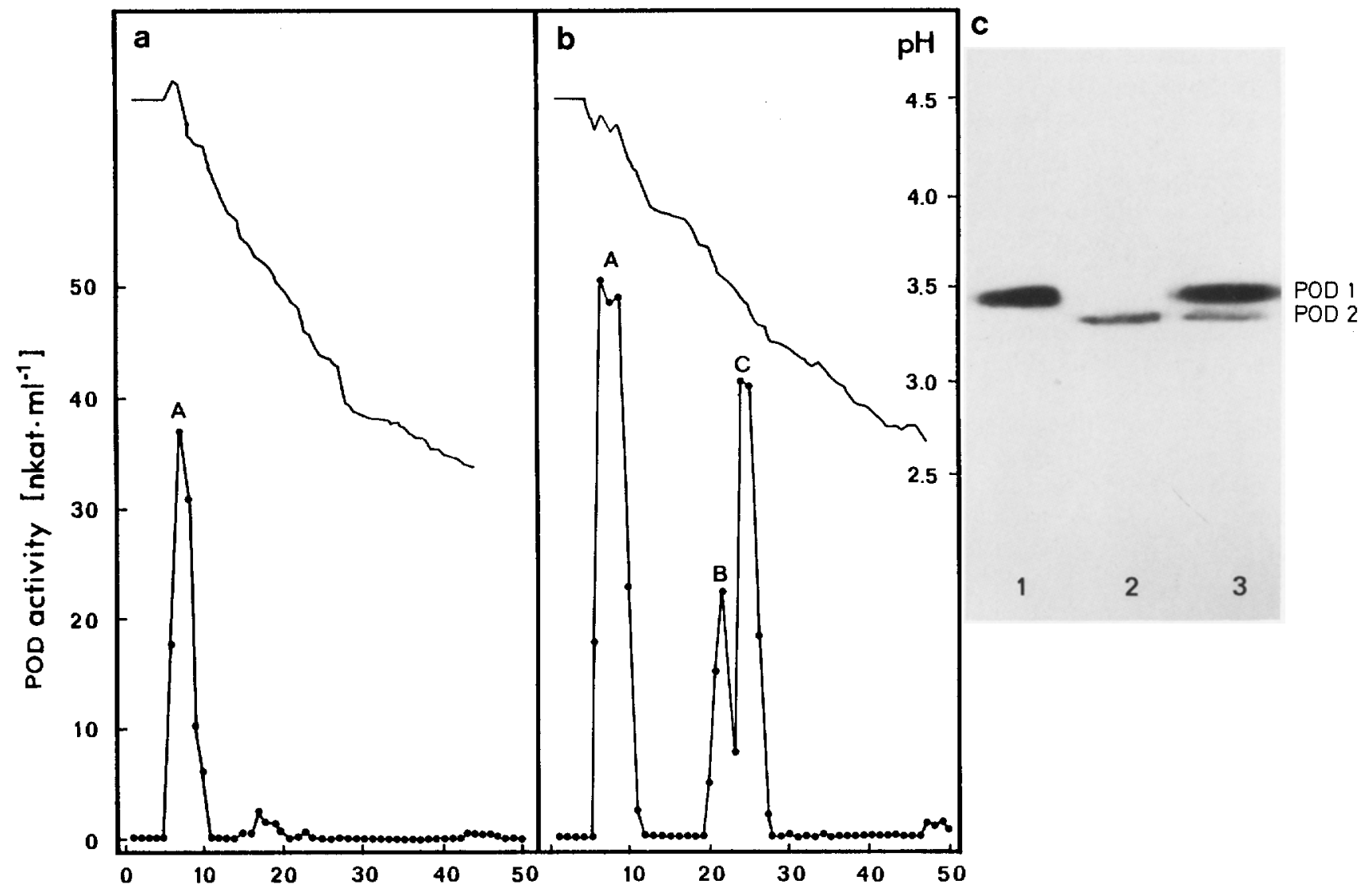

\section{fraction number}

Fig. 6a-c. Separation of POD forms by chromatofocusing on DEAE-Si 500. The IWF was isolated from talcum-treated control leaves of $V$. sinensis (a) and leaves inoculated with Uromyces viciaefabae (b). Samples were taken $48 \mathrm{~h}$ after the treatment. The column ( $8 \mathrm{~mm}$ i.d., $170 \mathrm{~mm}$ long) was equilibrated with $25 \mathrm{mM} \beta$-alanine$\mathrm{HCl}, \mathrm{pH} 4.5$, and eluted with $0.2 \%$ Servalyt $2-4, \mathrm{pH} 2.5$. The flow rate was $15 \mathrm{ml} \cdot \mathrm{h}^{-1}$, the fraction size $1.5 \mathrm{ml}$. Washing with $1 \mathrm{M}$ $\mathrm{NaCl}$ did not elute further POD activity. c Native basic polyacrylamide gel of peaks $\mathrm{B}$ and $\mathrm{C}$ obtained by chromatofocusing. Peroxidase activity was visualized by using 3-amino-9-ethylcarbazole as the substrate; lane 1, peak B $(50 \mu \mathrm{l})$; lane 2 , peak $\mathrm{C}$ $(50 \mu \mathrm{l})$; and lane 3 , a mixture of peaks $\mathrm{B}$ and $\mathrm{C}(50 \mu \mathrm{l}+50 \mu \mathrm{l})$
Table 1. Substrate specificity of pathogenesis-inducible PODs from $V$. sinensis leaves

\begin{tabular}{|c|c|c|c|c|c|c|}
\hline \multirow[t]{2}{*}{ Substrate } & \multicolumn{3}{|c|}{ POD activityc } & \multicolumn{3}{|c|}{ Relative POD activity ${ }^{d}$} \\
\hline & peak $A$ & peak B & peak $\mathrm{C}$ & peak $A$ & peak $B$ & peak $\mathrm{C}$ \\
\hline Guajacol $^{a}$ & 25 & 25 & 25 & 1 & 1 & 1 \\
\hline $\begin{array}{l}\text { 3-Amino-9- } \\
\text { ethylcarbazol }\end{array}$ & 0.0017 & 0.0016 & 0.0016 & 1 & 0.94 & 0.94 \\
\hline $\begin{array}{l}\text { Coniferyl } \\
\text { alcohol }^{a}\end{array}$ & 57.58 & 115.15 & 113.64 & 1 & 2 & 1.97 \\
\hline
\end{tabular}

a POD activity in nkat

${ }^{b}$ POD activity in $\triangle \mathrm{E}_{410 \mathrm{~nm}} \cdot \mathrm{min}^{-1}$

${ }^{c}$ Equal activities of the peak fractions (25 nkat guajacol per $\mathrm{ml}$ ) were used

${ }^{d}$ Relative activities of the induced POD forms (peak B and C) were expressed as the ratio of the absolute POD activities of peak A. were almost undetectable in IWF recovered from talcum control plants but present at high levels in plants inoculated with the non-pathogenic rust fungus (Fig. 6a, b). The peak fractions $\mathrm{B}$ and $\mathrm{C}$ correspond to POD1 and POD2 in basic polyacrylamide gels (Fig. 6c). In all experiments, more than $80 \%$ of POD activity was recovered after chromatofocusing.
Molecular-weight determination of extracellular $P O D$ forms. Molecular-weight determination was performed by Sephadex G75-SF chromatography. After application of total IWF, POD activity elutes as one poorly resolved peak with a maximum corresponding to $37.8 \mathrm{kDa}$. Applying basic POD forms recovered after chromatofocusing (peak A, Fig. 6) to Sephadex G75-SF 
chromatography, an apparent molecular weight ranging from 30 to $36.5 \mathrm{kDa}$ was found. When a mixture of acidic POD forms (peaks B and C) were applied, an apparent molecular weight of $37.6 \mathrm{kDa}$ was determined.

Substrate specificity of non-pathogen-inducible $P O D$ forms. To analyze the substrate specificity of acidic POD forms separated by chromatofocusing (peaks A, B and C, Fig. 6), the two synthetic substrates guajacol and 3-amino-9-ethylcarbazol and the natural substrate coniferyl alcohol were used. The activities of the acidic POD forms (peaks B and C) with different substrates were compared to the activities of peak A. Equivalent activities ( 25 nkat, measured with guajacol as the standard substrate) were used in each assay (Table 1). While all POD forms showed comparable activities with 3-amino9-ethylcarbazol, the inducible acidic POD forms were twice as active as the basic PODs when coniferyl alcohol was the substrate.

\section{Discussion}

In compatible and non-host interactions of Vigna sinensis with different Uromyces species, the rust fungi develop similarly until formation of haustorial mother cells. While $U$. vignae is able to form primary and secondary haustoria and to establish biotrophy, only $8 \%$ of the sporelings of $U$. appendiculatus give rise to haustoria; $U$. viciae-fabae is not able to form haustoria at all. The latter combinations are typical non-host interactions (Elmhirst and Heath 1987). Demonstration of autofluorescence and phloroglucinol/HCl-positive material in the area of contact between mesophyll cells and haustorial mother cells indicates that lignification could be involved in early defence against rust fungi in both nonhost interactions. Therefore, the time-courses of PAL and POD activities in relation to deposition of lignin or lignin-like material in mesophyll cell walls was examined.

In contrast to control plants and plants infected with the pathogen $U$. vignae, which show no significant change in PAL activity up to $48 \mathrm{~h}$ p.i., this enzyme is significantly increased as early as $10 \mathrm{~h}$ p.i. with the nonpathogens $U$. appendiculatus and $U$. viciae-fabae. The increase of PAL activity thus appears at a time when the rust fungi are about to penetrate through the stomata into the substomatal chamber where they differentiate substomatal vesicles and infection hyphae. To study the regulation of PAL in cowpea plants inoculated with compatible and non-pathogenic rust fungi, monospecific antiserum raised against PAL from parsley was used to probe Western blots. The facts that PAL activity in cowpea crude extracts can be titrated with the anti PAL serum and that the single band detected on Westernblotted cowpea proteins was at a position corresponding to approx. $80 \mathrm{kDa}$ are taken as proof that the protein detected by the antibody is $V$. sinensis PAL protein. The PAL protein of several other sources has been shown to have a molecular weight of around $80 \mathrm{kDa}$ (Jones 1984 ; Cramer et al. 1985). The time-course of alteration in PAL activity in non-host interactions correlates with the changes in intensity of the PAL bands on the blots and indicates that de novo synthesis is involved in PAL induction (Jones 1984). It can be concluded that the plant must have perceived a signal from the potentially attacking rust fungus much sooner than $10 \mathrm{~h}$ p.i. Interestingly, Paradies et al. (1979) have shown that rust fungi can induce stress responses, such as ethylene production in plants, during germ-tube growth and penetration of the stomata.

Early increases of PAL activity also seems to be involved in host resistance of gramineae to rust infections. Yamamoto et al. (1977) showed that in compatible and incompatible interactions of oat and Puccinia coronata, a first maximum of PAL activity occurred $12 \mathrm{~h}$ p.i. A second maximum 30 to $45 \mathrm{~h}$ p.i. was only found in the incompatible interaction. Moreover, in compatible and incompatible interactions of wheat and $P$. graminis, maximal PAL activities were measured 8 to $16 \mathrm{~h} \mathrm{p.i.,} \mathrm{followed}$ by another maximum only in the resistant variety coincident with haustoria formation and hypersensitive response (Moerschbacher et al. 1988). In contrast to rustinfected gramineae, host and non-host systems of $V$. sinensis showed significant differences in PAL activity as early as $10 \mathrm{~h}$ p.i. In both non-host systems the enzyme activity was substantially increased, whereas the host system did not differ from control plants. Moerschbacher et al. (1986) have shown that an elicitor isolated from $P$. graminis f. sp. tritici induced both PAL activity and lignification in wheat. Lignification is discussed as a resistance mechanism in wheat, since phytoalexins have not been detected in Triticum species up to now.

However, in the case of $V$. sinensis, PAL activity induced by non-pathogenic rust fungi could also lead to phytoalexin synthesis (Munn and Drysdale 1975). In order to demonstrate biochemically the involvement of lignification in non-host resistance of cowpea, the timecourse and substrate specificity of extracellular POD activity were investigated. The importance of these enzymes in lignification is emphasized by the fact that in most (though not all) fungus-plant interactions, POD activities are higher in resistant than in susceptible interactions. Lignin polymerization by apoplasmic PODs thus seems to be important for the expression of resistance to fungal pathogens in plants.

After inoculation with the pathogenic rust $U$. vignae and the non-pathogens $U$. appendiculatus and $U$. viciaefabae, increased extracellular acidic POD activity was found $24 \mathrm{~h}$ p.i. in $V$. sinensis. This increase was much more pronounced after inoculation with the non-pathogenic rusts. In wheat infected with $P$. graminis f. sp. tritici, increased POD activities were found $24 \mathrm{~h}$ p.i. in both compatible and incompatible interactions; however, differences started to occur 3 days p.i. (Moerschbacher et al. 1988). The increasing POD activities were accompanied by increasingly lignified cell walls. There is time-coincidence of increased POD activities and formation of haustoria; the enzymes are either induced at the translation level or specific isoforms are activated (Catedral and Daly 1976; Reisener et al. 1986; Kerby and Somerville 1989).

Native PAGE indicated that rust fungi induce or 
activate two extracellular acidic POD forms in cowpea to different levels, starting at $16 \mathrm{~h}$ p.i. However, induction or activation of acidic POD forms is not necessarily a specific response to rust fungi. Wagih and Coutts $(1982 \mathrm{a}, \mathrm{b})$ found that $V$. sinensis infected with Tobacco Necrosis Virus or osmotically stressed by treatment with $0.5 \mathrm{M}$ mannitol showed similar alterations in the acidic POD zymogram. Comparable changes in the POD pattern were also found in wheat varieties that were either host resistant or susceptible to $P$. graminis (Catedral and Daly 1976; Reisener et al. 1986) and in barley varieties incompatible with the powdery mildew fungus Erisyphe graminis (Kerby and Somerville 1989).

In contrast, in oat leaves infected with either the pathogenic rust fungus $P$. coronata or with the nonpathogens $P$. recondita or $P$. graminis, no significant alterations in POD activities were found although these enzymes are inducible by abiotic stress factors (Fink et al. 1990). Pathogen-induced lignification, however, has not been found in oat (Yamamoto et al. 1978), indicating that these reactions are not responsible for defence against rust fungi in these species.

A role of PODs in lignification is deduced from their localization in the apoplast and their high affinity to the naturally occurring lignin monomer coniferyl alcohol (Harkin and Obst 1973; Mäder et al. 1977; Gaspar 1986; Cassab and Varner 1988). Acidic POD forms usually fulfill these conditions, but exceptions have been reported (Van Huystee 1987). Extracellular non-pathogen-inducible acidic PODs of $V$. sinensis show a higher relative affinity for coniferyl alcohol than the pooled basic POD forms of the apoplast, indicating an involvement in rust-induced lignification reactions.

The enzymes POD and PAL appear to be involved in the plants' strategy to inhibit fungal growth, since the increase in PAL activity is followed by an increase in POD activity and subsequently lignin or lignin-like material is deposited in cowpea cell walls. This defence strategy seems to be activated gradually: $U$. viciae-fabae, which is stopped completely during formation of haustorial mother cells, induces high levels of PAL and POD activities, $U$. appendiculatus, which is able to produce some haustoria in the mesophyll of $V$. sinensis, induces only intermediate levels of these enzymes. In the compatible interaction, PAL and POD activities are indistinguishable from the low levels found in control plants. Cinnamyl $\left(\mathrm{NADP}^{+}\right)$alcohol dehydrogenase (CADH) which is specific for lignification was detectable in cowpea plants, but no gradual differences were found during pathogenesis involving different rust fungi (data not shown). Thus, CADH does not seem to be regulatory in the expression of defence reactions.

However, growth of the non-pathogens was also stopped in cowpea tissue where no lignin formation was observed. Therefore, factors other than or in addition to lignification must be involved in the expression of non-host resistance. In addition, extracellular PODs could be involved in cross-linking of pectin or in linking of extensin monomers (Fry 1986), resulting in increased mechanical strength of the cell wall. Cell wall modifications like these, leading to increased mechanical resistance could delay fungal development so that phytoalexins could be synthesized to fungistatic or fungitoxic levels (Ride 1983). Phytoalexin synthesis and lignification of cell walls in response to rust fungi could explain the necessity of PAL induction. A delay in fungal development could also allow the formation of defensive hydrolytic enzymes like $\beta$-1,3-glucanases and-or chitinases (Fink et al. 1990). The role of these enzymes in rust-inoculated cowpea is currently being investigated.

We are indebted to Professor K. Hahlbrock and Dr. E. Kombrink (Max Planck Institut für Züchtungsforschung, Köln, FRG) for the generous gift of monospecific antiserum to PAL from parsley and to Dr. G. Sweet (Universität Konstanz, FRG) for critically reading the manuscript. Grant to K.M. and a postdoctoral grant to H.D. from the Deutsche Forschungsgemeinschaft are also acknowledged.

\section{References}

Ando, Y., Ehara, Y., Yamanaka, S. (1984) Release of antifungal phenolic compounds from cucumber mosaic virus-infected and noninfected cowpea protoplasts. Phytopath. Z. 110, 354-359

Bailey, J.A. (1973) Production of antifungal compounds in cowpea (Vigna sinensis) and pea (Pisum sativum) after virus infection. J. Gen. Microbiol. 75, 119-123

Cassab, G.I., Varner, J.E. (1988) Cell wall proteins. Annu. Rev. Plant Physiol. Plant Mol. Biol. 39, 321-353

Catedral, F., Daly, J.M. (1976) Partial characterization of peroxidase isoenzymes from rust-affected wheat leaves. Phytochemistry $15,627-631$

Coutts, R.H.A. (1978) Alterations in the soluble protein patterns of tobacco and cowpea leaves following inoculation with tobacco necrosis virus. Plant Sci. Lett. 12, 189-197

Cramer, C.L., Ryder, T.B., Bell, J.N., Lamb, C.L. (1985) Rapid switching of plant gene expression induced by fungal elicitor. Science 227, 1240-1242

Deising, H., Rudolph, H. (1987) Nitrate-induced de novo synthesis and regulation of NAD(P)H nitrate reductase from Sphagnum. Physiol. Plant. 71, 477-482

Ehara, Y., Yamanaka, S. (1981) A method of extraction of fungitoxic compounds from leaves infected with virus. Physiol. Plant Pathol. 18, 107-111

Elmhirst, J.F., Heath, M.C. (1987) Interactions of the bean rust and cowpea rust fungi with species of the Phaseolus-Vigna plant complex. I. Fungal growth and development. Can. J. Bot. 65, 1096-1107

Elmhirst, J.F., Heath, M.C. (1989) Interactions of the bean rust and cowpea rust fungi with species of the Phaseolus-Vigna plant complex. II. Histological responses to infection in heat-treated and untreated leaves. Can. J. Bot. 67, 58-72

Espelie, K.E., Kolattukudy, P.E. (1985) Purification and characterization of an abscisic acid-inducible anionic peroxidase associated with suberization in potato (Solanum tuberosum). Arch. Biochem. Biophys. 240, 539--545

Fink, W., Liefland, M., Mendgen, K. (1990) Extracellular chitinases and $\beta$-1,3-glucanases in compatible and nonhost interactions of oat leaves and cereal rusts. Physiol. Mol. Plant Pathol. 37, 309-321

Fry, C.S. (1986) Cross-linking of matrix polymers in the growing cell walls of angiosperms. Annu. Rev. Plant Physiol. 37, 165-186

Gaspar, T.H. (1986) Integrated relationship of biochemical and physiological peroxidase activities. In: Molecular and physiological aspects of peroxidases, pp. 455-468, Greppin, H., ed. Université de Genève, Genève

Gaspar, T.H., Penel, C., Thorpe, T., Greppin, H. (1982) Peroxidases 1970-1980. A survey of their biochemical and physiological roles in higher plants. Université de Genève, Genève 
Graham, R.C., Lundholm, U., Karnovsky, M.J. (1964) Cytochemical demonstration of peroxidase activity with 3-amino-9-ethylcarbazole. J. Histochem. Cytochem. 13, 150-152

Green, E.N., Hadwiger, A., Graham, S.O. (1975) Phenylalanine ammonia-lyase, tyrosine ammonia-lyase and lignin in wheat inoculated with Erisyphe graminis f. sp. tritici. Phytopathology 65, 1071-1074

Harkin, J.M., Obst, J.R. (1973) Lignification in trees: Indication of exclusive peroxidase participation. Science 180, 296-298

Hattori, T., Ohta, Y. (1985) Induction of phenylalanine ammonialyase activity and isoflavone glucoside accumulation in suspension-cultured cells of red bean, Vigna angularis, by phytoalexin elicitors, vanadate, and elevation of medium $\mathrm{pH}$. Plant Cell Physiol. 26, 1101-1110

Heath, M.C. (1972) Ultrastructure of host and non-host interactions with rust fungi. Physiol. Plant Pathol. 10, 73-88

Heath, M.C. (1980) Reactions of the nonsuscepts to fungal pathogens. Annu. Rev. Phytopathol. 18, 221-236

Heath, M.C. (1987) Host vs. nonhost resistance. In: Molecular strategies for crop production, pp. 25-34, Arntzen, C.H.J., Ryan, C., eds. Alan Liss, New York

Jones, D.H. (1984) Phenylalanine ammonia-lyase: Regulation of its induction, and its role in plant development. Phytochemistry 23, 1349-1359

Kerby, K., Somerville, S. (1989) Enhancement of specific intercellular peroxidases following inoculation of barley with Erysiphe graminis f. sp. hordei. Physiol. Mol. Plant Pathol. 35, 323-337

Kyhse-Andersen, J. (1984) Electroblotting of multiple gels: a simple apparatus without buffer tank for rapid transfer of proteins from polyacrylamide to nitrocellulose. J. Biochem. Biophys. Meth. 10, 203-209

Laemmli, U.K. (1970) Cleavage of structural proteins during the assembly of the head of bacteriophage T4. Nature 227, 680-685

Luke, H.H., Barnett, R.D., Pfahler, P.L. (1987) Xenoparasitenonhost reactions in Puccinia-gramineae pathosystems. Phytopathology 77, 1488-1491

Mäder, M., Nessel, A., Bopp, M. (1977) Über die Bedeutung der Peroxidase-Isoenzymgruppen des Tabaks anhand einiger biochemischer Eigenschaften. II. pH-Optima, MichaelisKonstanten, Maximale Oxidationsraten. Z. Pflanzenphysiol. 82, 247-260

Maurer, H.R. (1971) Disc electrophoresis. De Gruyter, Berlin New York

Mendgen, K. (1975) Ultrastructural demonstration of different peroxidase activities during the bean rust infection process. Physiol. Plant Pathol. 6, 275-282

Moerschbacher, B., Heck, B., Kogel, K.H., Obst, O,, Reisener, H.J. (1986) An elicitor of the hypersensitive response in wheat leaves isolated from the rust fungus Puccinia graminis f. sp. tritici. II. Induction of enzymes correlated with the biosynthesis of lignin. Z. Naturforsch. 41c, 839-844

Moerschbacher, B.M., Noll, U., Flott, B.E., Reisener, H.J. (1988) Lignin biosynthetic enzymes in stem rust infected, resistant and susceptible near-isogenic wheat lines. Physiol. Mol. Plant Pathol. 33, 33-46
Munn, B.C., Drysdale, B. (1975) Kievitone production and phenylalanine ammonia-lyase activity in cowpea. Phytochemistry 14, 1303-1307

Paradies, I., Hümme, B., Hoppe, H.H., Heitefuss, R., Elstner, E.F. (1979) Induction of ethylene formation in bean Phaseolus vulgaris hypocotyl segments by preparations isolated from germ tube cell walls of Uromyces phaseoli. Planta 146, 193-197

Petreño, M.A., Ros Barcelo, A., Sabater, F., Munoz, R. (1989) Control by $\mathrm{pH}$ of cell wall peroxidases activity in volved in lignification. Plant Cell Physiol. 30, 237-241

Ralton, J.E., Howlett, B.J., Clarke, A.E., Irwin, J.A.G., Imrie, B. (1988) Interaction of cowpea and Phytophthora vignae inheritance of resistance and production of phenylalanine ammonia-lyase as a resistance response. Physiol. Mol. Plant Pathol. 32, 89-103

Rathmell, W.G., Sequeira, L. (1974) Soluble peroxidase in fluids from the intercellular spaces of tobacco leaves. Plant Physiol. 53, $317-318$

Reisener, H.J., Tiburzy, R., Kogel, K.H., Moerschbacher, B., Heck, B. (1986) Mechanism of resistance of wheat against stem rust in the Sr5/P5 interaction. In: Biology and molecular biology of plant-pathogen interactions, pp. 141-148, Bailey, J.A., ed. Springer, New York Berlin Heidelberg

Ride, J.P. (1983) Cell walls and other structural barriers of defence. In: Biochemical plant pathology, pp. 215-236, Callow, J.A., ed. John Wiley and Sons, Chichester New York Brisbane

Rohringer, R., Kim, W.K., Samborsky, D.J., Howes, N.K. (1976) Calcofluor: an optical brightener for fluorescence microscopy of fungal plant parasites in leaves. Phytopathology 67, 808-810

Rohringer, R., Ebrahim-Nesbat, F., Wolf, G. (1983) Proteins in intercellular washing fluids from leaves of barley (Hordeum vulgare L.). J. Exp. Bot. 34, 1589-1605

Tiburzy, R., Reisener, H.J. (1990) Resistance of wheat to Puccinia graminis $\mathrm{f}$. $\mathrm{sp}$. tritici: Association of the hypersensitive reaction with the cellular accumulation of lignin-like material and callose. Physiol. Mol. Plant Pathol. 36, 109-120

Van Huystee, R.B. (1987) Some molecular aspects of plant peroxidase biosynthetic studies. Annu. Rev. Plant Physiol. 38, 205-219

Wagih, E.E., Coutts, R.H.A. (1981) Similarities in the soluble protein profiles of leaf tissue following either a hypersensitive reaction to virus infection or plasmolysis. Plant Sci. Lett. 21, 61-69

Wagih, E.E., Coutts, R.H.A. (1982a) Peroxidase, polyphenoloxidase and ribonuclease in tobacco necrosis virus infected or mannitol osmotically-stressed cowpea and cucumber tissue. I. Quantitative alterations. Phytopath. Z. 104, 1-12

Wagih, E.E., Coutts, R.H.A. (1982b) Peroxidase, polyphenoloxidase and ribonuclease in tobacco necrosis virus infected or mannitol osmotically-stressed cowpea and cucumber tissue. II. Qualitative alterations. Phytopath. Z. 104, 124-137

Yamamoto, H., Hokin, H., Tani, T., Kadota, G. (1977) Phenylalanine ammonia-lyase in relation to the crown rust resistance of oat leaves. Phytopath. Z. 90, 203-211

Yamamoto, H., Hokin, H., Tani, T. (1978) Peroxidase and polyphenoloxidase in relation to the crown rust resistance of oat leaves. Phytopath. Z. 91, 193-202 